\title{
Fast shrinkage of tropical glaciers in Colombia
}

\author{
Jorge Luis CEBALLOS, ${ }^{1}$ Christian EUSCÁTEGUI, ${ }^{1}$ Jair RAMÍREZ, ${ }^{2}$ Marcela CAÑON, ${ }^{3}$ \\ Christian HUGGEL, ${ }^{4}$ Wilfried HAEBERLI, ${ }^{4}$ Horst MACHGUTH ${ }^{4}$ \\ ${ }^{1}$ Instituto de Meteorología, Hidrología y Estudios Ambientales, Bogotá, Colombia \\ E-mail: jorgec@ideam.gov.co \\ ${ }^{2}$ Instituto Colombiano de Geología y Minería, Bogotá, Colombia \\ ${ }^{3}$ Parques Nacionales de Colombia, Bogotá, Colombia \\ ${ }^{4}$ Department of Geography, University of Zürich-Irchel, Winterthurerstrasse 190, CH-8057 Zürich, Switzerland
}

\begin{abstract}
As a consequence of ongoing atmospheric temperature rise, tropical glaciers belong to the unique and threatened ecosystems on Earth, as defined by the Intergovernmental Panel on Climate Change (Houghton and others, 2001). Worldwide glacier monitoring, especially as part of the Global Climate Observing System (GCOS), includes the systematic collection of data on such perennial surface ice masses. Several peaks in the sierras of Colombia have lost their glacier cover during recent decades. Today, high-altitude glaciers still exist in Sierra Nevada de Santa Marta, in Sierra Nevada del Cocuy and on the volcanoes of Nevados del Ruiz, de Santa Isabel, del Tolima and del Huila. Comparison of reconstructions of maximum glacier area extent during the Little Ice Age with more recent information from aerial photographs and satellite images clearly documents a fast-shrinking tendency and potential disappearance of the remaining glaciers within the next few decades. In the past 50 years, Colombian glaciers have lost $50 \%$ or more of their area. Glacier shrinkage has continued to be strong in the last 15 years, with a loss of $10-50 \%$ of the glacier area. The relationship between fast glacier retreat and local, regional and global climate change is now being investigated. Preliminary analyses indicate that the temperature rise of roughly $1^{\circ} \mathrm{C}$ in the last 30 years recorded at high-altitude meteorological stations exerts a primary control on glacier retreat. The investigations on the Colombian glaciers thus corroborate earlier findings concerning the high sensitivity of glaciers in the wet inner tropics to temperature rise. To improve understanding of fast glacier retreat in Colombia, a modern monitoring network has been established according to the multilevel strategy of the Global Terrestrial Network for Glaciers (GTN-G) within GCOS. The observations are also contributions to continued assessments of hazards from the glacier-covered volcanoes and to integrated global change research in mountain biosphere reserves.
\end{abstract}

\section{INTRODUCTION}

High-altitude glaciers at low latitudes are recognized as sensitive indicators of regional and global climate change (Kaser and Georges, 1999; Francou and others, 2003). Given the ongoing atmospheric temperature rise, the Intergovernmental Panel on Climate Change report (Houghton and others, 2001) has defined tropical glaciers as unique and threatened ecosystems on Earth. Unlike midand high-latitude glaciers, however, they have rarely been studied (Kaser, 1999). There has been a particular scarcity of glaciological studies from the inner tropics. Inner-tropical conditions are characterized by more-or-less continuous precipitation throughout the year, with two precipitation peaks, whereas the outer tropics show clearly pronounced wet and dry seasons (Kaser and Osmaston, 2002). Glaciers in the inner tropics are actually rare, the only surviving examples being in east Africa (Hastenrath, 1989), New Guinea (Hope and others, 1976), Ecuador (Favier and others, 2004), Venezuela (Schubert, 1972) and Colombia (Flórez, 1992). Mass-balance studies are especially rare in these areas.

In Colombia, glaciers can be found at elevations higher than $\sim 4700 \mathrm{~m}$ a.s.l. depending on local meteorological and topographic conditions. Glacierized mountain peaks reach 5100-5700 ma.s.l. Six major ice masses presently exist in Colombia (Fig. 1): Sierra Nevada de Santa Marta, Sierra Nevada del Cocuy and Nevados del Ruiz, de Santa Isabel, del Tolima and del Huila. Glacierized areas in these mountains currently range from about 1 to $20 \mathrm{~km}^{2}$. Strong glacier retreat during the 20th century has led to the disappearance of eight nevados (glacierized areas). The small elevation range of most Colombian glaciers makes them particularly vulnerable to further disappearance in view of continuing atmospheric warming. Continuous monitoring of Colombian glaciers and their changes is therefore an essential task. Colombian glaciers have been observed rather irregularly, and very few studies have been published in the international literature, especially with regard to glacier fluctuations in the last decade. The present paper therefore aims at documenting the current state of glaciers in Colombia and their rapid retreat in recent decades, as well as at preliminary analysis of the ice-loss forcing mechanisms. The paper is based on glaciological studies performed by the Instituto de Meteorología, Hidrología y Estudios Ambientales (IDEAM), the Instituto Colombiano de Geología y Minería (INGEOMINAS), the Instituto Geográfico 'Agustín Codazzi' (IGAC) and a recently initiated research program involving the University of Zürich as part of a cooperation between the Colombian and Swiss governments.

\section{GLACIER MONITORING IN COLOMBIA}

Regular observations of glacier fluctuations have been carried out in Colombia since the mid-1980s. The glaciers 

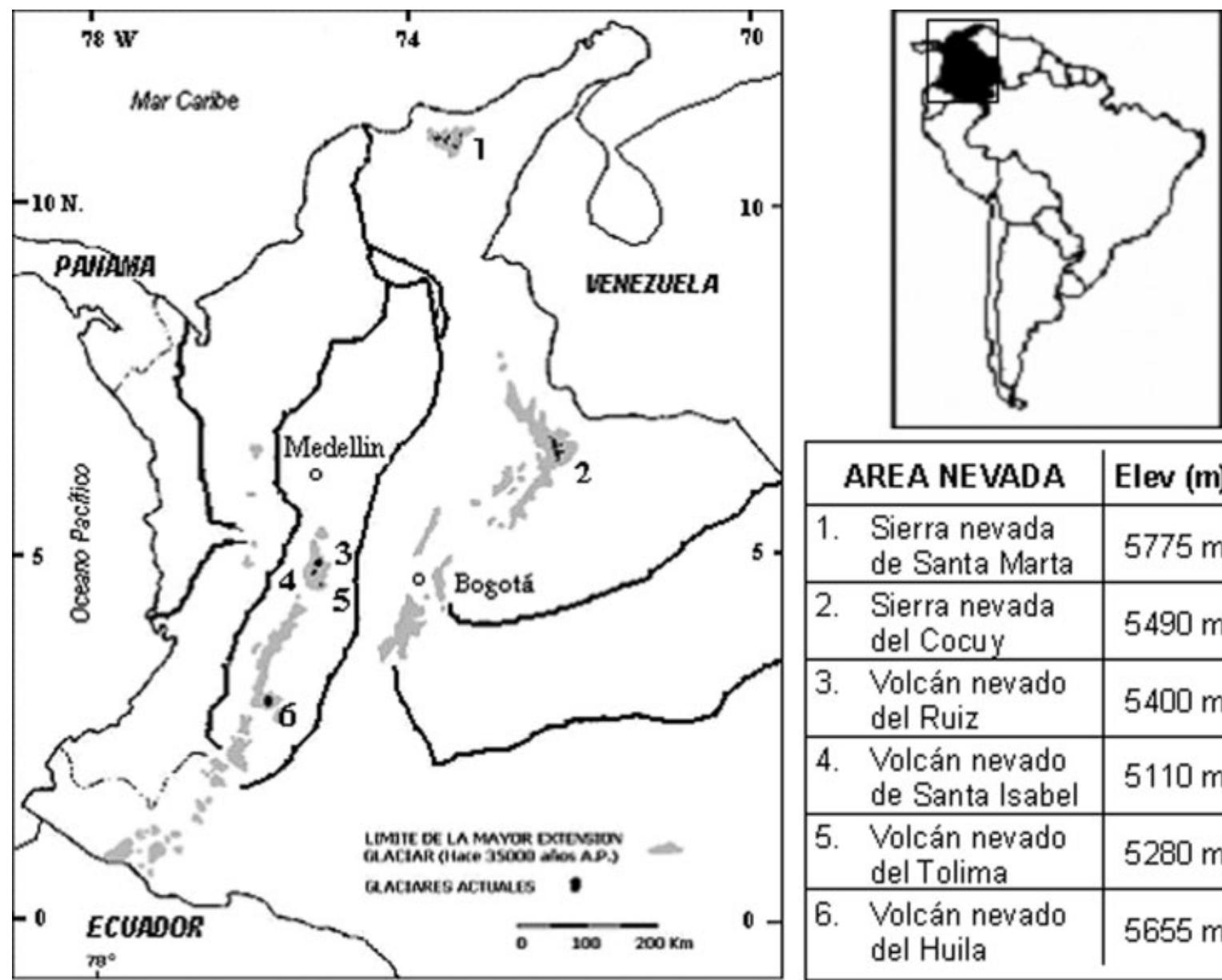

\begin{tabular}{|ll|l|}
\hline \multicolumn{2}{|c|}{ AREA NEVADA } & Elev $(\mathrm{m})$ \\
\hline $\begin{array}{l}\text { 1. } \\
\text { Sierra nevada } \\
\text { de Santa Marta }\end{array}$ & $5775 \mathrm{~m}$. \\
\hline 2. & $\begin{array}{l}\text { Sierra nevada } \\
\text { del Cocuy }\end{array}$ & $5490 \mathrm{~m}$. \\
\hline 3. & $\begin{array}{l}\text { Volcán nevado } \\
\text { del Ruiz }\end{array}$ & $5400 \mathrm{~m}$. \\
\hline 4. & $\begin{array}{l}\text { Volcán nevado } \\
\text { de Santa lsabel }\end{array}$ & $5110 \mathrm{~m}$. \\
\hline 5. & $\begin{array}{l}\text { Volcán nevado } \\
\text { del Tolima }\end{array}$ & $5280 \mathrm{~m}$. \\
\hline 6. & $\begin{array}{l}\text { Volcán nevado } \\
\text { del Huila }\end{array}$ & $5655 \mathrm{~m}$. \\
\hline
\end{tabular}

Fig. 1. Map of Colombia showing the six glacierized mountain ranges, with current glacier extent (black) and Ice Age (35000years BP) glacier extent (grey).

on Nevado de Santa Isabel and in Sierra Nevada del Cocuy were among the first to be studied. Methods such as airphoto interpretation were used to reconstruct advance and retreat periods of the glaciers since the last ice age, when they reached down to about $3000 \pm 200$ ma.s.l. (Flórez, 1992). Glacier fluctuations are known in more detail since the Little Ice Age (LIA; approximately 1850). The 1850 glacierized area was assessed with the aid of morainic deposits which are generally clearly visible in the field and on aerial photographs, and based on further studies (Flórez, 1992). Air-photo and satellite image analysis was used to reconstruct approximately a decadal record of glacier area change from the 1950s to the present.

Glacier monitoring in Colombia is not only motivated by climate-change considerations but has received important impetus from the hazardous interaction of ice with volcanic activity. In fact, Colombia has suffered by far the largest glacier-volcano interaction and one of the most severe volcanic disasters ever: the 1985 Nevado del Ruiz catastrophe, triggered by a medium-size eruption producing devastating lahars which claimed the lives of more than 20000 people (e.g. Thouret, 1990). This event marked the onset of glacier studies in the context of volcano-ice hazards. Examples of such efforts are studies on Nevado del Tolima, Nevado del Ruiz (Thouret, 1990; Ramírez and Guarnizo, 1994) and Nevado del Huila (Pulgarín and others, 1996) volcanoes and most recently an overview assessment of hazards of all glacier-clad volcanoes (Huggel and others, in press). IGAC initiated glacier observations in the 1980s which IDEAM has continued for the last 10 years. INGEOMINAS is primarily in charge of glacier monitoring in connection with volcanic hazard assessments. Further contributions, mainly based on photogrammetric analyses, were provided by Linder (1991) and Braitmeier (2003). Most recently, efforts are being undertaken to better integrate Colombia into international glacier-monitoring programs according to strategies such as the multilevel concept of the Global Terrestrial Network for Glaciers (GTN-G) within the Global Climate Observing System (GCOS) and implemented by the World Glacier Monitoring Service (WGMS). In accordance with the hierarchical approach proposed by GCOS and WGMS, three monitoring levels with different degrees of detail were defined in Colombia:

1. glacier inventory studies assessing the area of all Colombian glaciers with a repetition rate of 5-10 years (reduced to 2-5 years in some areas);

2. glacier length observations on selected glaciers in Sierra Nevada del Cocuy and Nevados de Santa Isabel and del Ruiz; and

3. mass-balance studies on a sub-catchment of Nevado de Santa Isabel along a west-east transect.

Inventory studies (1) are performed primarily by analysis of satellite images, since access to some of the glacierized 
Table 1. Glacier area change in the six glacierized mountain ranges of Colombia from the Little Ice Age to the present (data sources: Flórez, 1992; Pulgarín and others, 1996; this study)

\begin{tabular}{|c|c|c|c|c|}
\hline \multirow[t]{2}{*}{$\begin{array}{l}\text { Glacierized } \\
\text { mountain range }\end{array}$} & \multirow[t]{2}{*}{ Year } & Area & Area loss & $\begin{array}{l}\text { Annual } \\
\text { area loss }\end{array}$ \\
\hline & & $\mathrm{km}^{2}$ & $\mathrm{~km}^{2}$ & $\mathrm{~km}^{2} \mathrm{a}^{-1}$ \\
\hline $\begin{array}{l}\text { Sierra Nevada } \\
\text { de Santa Marta }\end{array}$ & $\begin{array}{l}1850 \\
1939 \\
1954 \\
1981 \\
1989 \\
1995 \\
2002\end{array}$ & $\begin{array}{l}82.6 \\
21.4 \\
19.4 \\
16.1 \\
12 \\
11.1 \\
7.9\end{array}$ & $\begin{array}{c}61.2 \\
2 \\
3.3 \\
4.1 \\
0.9 \\
3.2\end{array}$ & $\begin{array}{l}0.69 \\
0.13 \\
0.12 \\
0.51 \\
0.15 \\
0.45\end{array}$ \\
\hline $\begin{array}{l}\text { Sierra Nevada } \\
\text { del Cocuy }\end{array}$ & $\begin{array}{l}1850 \\
1955 \\
1986 \\
1994 \\
2003\end{array}$ & $\begin{array}{r}148.7 \\
38.9 \\
31.4 \\
23.7 \\
19.8\end{array}$ & $\begin{array}{r}109.8 \\
7.4 \\
7.7 \\
3.9\end{array}$ & $\begin{array}{l}1.05 \\
0.24 \\
0.97 \\
0.43\end{array}$ \\
\hline $\begin{array}{l}\text { Volcán Nevado } \\
\text { del Ruiz }\end{array}$ & $\begin{array}{l}1850 \\
1959 \\
1975 \\
1985 \\
1986 \\
1990 \\
1997 \\
2002\end{array}$ & $\begin{array}{l}47.5 \\
21 \\
19.6 \\
18.7 \\
17 \\
14.1 \\
11.8 \\
10.3\end{array}$ & $\begin{array}{r}26.5 \\
1.4 \\
0.9 \\
1.7 \\
2.9 \\
2.8 \\
1.4\end{array}$ & $\begin{array}{l}0.24 \\
0.09 \\
0.09 \\
1.70 \\
0.72 \\
0.40 \\
0.28\end{array}$ \\
\hline $\begin{array}{l}\text { Volcán Nevado } \\
\text { de Santa Isabel }\end{array}$ & $\begin{array}{l}1850 \\
1946 \\
1959 \\
1987 \\
1995 \\
2002\end{array}$ & $\begin{array}{r}27.8 \\
10.8 \\
9.4 \\
6.4 \\
5.3 \\
3.3\end{array}$ & $\begin{array}{l}17 \\
1.4 \\
3 \\
1.1 \\
2.0\end{array}$ & $\begin{array}{l}0.18 \\
0.11 \\
0.11 \\
0.12 \\
0.29\end{array}$ \\
\hline $\begin{array}{l}\text { Volcán Nevado } \\
\text { del Tolima }\end{array}$ & $\begin{array}{l}1850 \\
1946 \\
1958 \\
1987 \\
1997 \\
2002\end{array}$ & $\begin{array}{l}8.6 \\
3.1 \\
2.7 \\
1.6 \\
1.2 \\
1.0\end{array}$ & $\begin{array}{l}5.5 \\
0.4 \\
1.1 \\
0.4 \\
0.1\end{array}$ & $\begin{array}{l}0.06 \\
0.03 \\
0.04 \\
0.04 \\
0.03\end{array}$ \\
\hline $\begin{array}{l}\text { Volcán Nevado } \\
\text { del Huila }\end{array}$ & $\begin{array}{l}1850 \\
1959 \\
1965 \\
1981 \\
1990 \\
1996 \\
2001\end{array}$ & $\begin{array}{l}33.7 \\
17.5 \\
16.3 \\
15.4 \\
13.9 \\
13.3 \\
12.9\end{array}$ & $\begin{array}{r}16.2 \\
1.2 \\
0.9 \\
1.5 \\
0.6 \\
0.3\end{array}$ & $\begin{array}{l}0.15 \\
0.20 \\
0.06 \\
0.17 \\
0.10 \\
0.06\end{array}$ \\
\hline Present total area & & 55.4 & & \\
\hline
\end{tabular}

areas in Colombia is restricted due to political problems or rough and remote terrain. Glacier length observations (2) are carried out once a year at approximately the same date on about a dozen glacier tongues of the above-mentioned icecapped mountain ranges. Mass-balance studies (3) have just been initiated and are a cooperative effort by several institutions to overcome the conceptual, logistic and climatic/meteorological challenges on the high-altitude glaciers. Results from mass-balance measurements in Colombia are therefore not yet available.

\section{GLACIER FLUCTUATIONS IN COLOMBIA}

During the LIA, ice masses in Colombia advanced to about $4200 \mathrm{~m}$ a.s.l. in the south of the country, to about $4400 \mathrm{~m}$ a.s.l. in the center and to about $4600 \mathrm{~m}$ a.s.l. in the north (Sierra Nevada de Santa Marta) and occupied a total area of about $374 \mathrm{~km}^{2}$ (Flórez, 1992). Following the end of the LIA, glaciers began to retreat rapidly, and eight glacierized areas disappeared during the 20th century (Flórez, 1992).

The current total glacierized area in Colombia is $55.4 \mathrm{~km}^{2}$ (year 2003), with glacier termini found at 4700-4900 m a.s.l. A record of the ice retreat in the second half of the 20th century was established, based on photogrammetric and satellite image analysis (Table 1). The measurements show a dramatic glacier recession in the 20th century, in their majority most pronounced from the mid-1980s to the present.

The regions most affected by glacier shrinkage are Sierra Nevada de Santa Marta and Nevado de Santa Isabel (Figs 2 and 3 ). In the former, a $50 \%$ area loss has been observed in the last 20 years, while the latter showed a $50 \%$ loss in just 15 years. Sierra Nevada del Cocuy and Nevados de Tolima and del Ruiz have also been greatly affected, losing 35-45\% of their glacier area in the last 15-17 years of the 20th century. The ice masses on Nevado del Ruiz were additionally affected by the 1985 volcanic eruption. Thouret (1990) states that $4.2 \mathrm{~km}^{2}$ of ice at the margin of the ice cap was missing after the eruption, with an estimated volume loss of $0.0616 \mathrm{~km}^{3}$. Thouret's study is, however, based on a pre-eruption ice surface area of $22.55 \mathrm{~km}^{2}$, a larger value than given in the present paper. Glaciers on Nevado del Huila showed a comparatively moderate shrinkage, with about a $20 \%$ loss in the last 20 years.

Glacier length measurements conducted since the 1980s reveal a similar picture of rapid retreat. On Nevado de Santa Isabel, glacier termini retreated $170-250 \mathrm{~m}$ in 15 years (19882003; Fig. 4), giving an annual retreat rate of 11-17 m. In Sierra Nevada del Cocuy, where the total glacier area is about six times larger than at Nevado de Santa Isabel, the retreat at some glacier tongues was nearly $500 \mathrm{~m}$ in the last 18 years (Fig. 5). This is a very large value since the total lengths of individual glaciers in the Cocuy region are about 1-1.5 km.

In addition to glacier area and length change observations, ice-thickness measurements were performed on Nevados del Ruiz, del Tolima and de Santa Isabel within the framework of volcanic monitoring. A ground-penetrating radar (GPR) of $10 \mathrm{MHz}$ frequency was used. Due to the volcanic hazards, the most extensive GPR measurements were carried out on Nevado del Ruiz, where a total of $6 \mathrm{~km}$ of radar profiles were accomplished (Fig. 6).

Irregularly spaced GPS measurements taken simultaneously with the GPR sounding were interpolated to generate a gridded surface topography. Another interpolation was applied using the ice-thickness measurements obtained from GPR sounding to get a regularly spaced bed topography. Comparison with the surface topography then allowed derivation of the ice volume on Nevado del Ruiz. Results are presented in Table 2 .

\section{DISCUSSION AND RELATIONSHIP OF GLACIER RETREAT TO CLIMATE}

In general, all glacierized regions in Colombia showed rapid glacier retreat in recent decades. On a regional level, differences in the rate of shrinkage can be distinguished and 


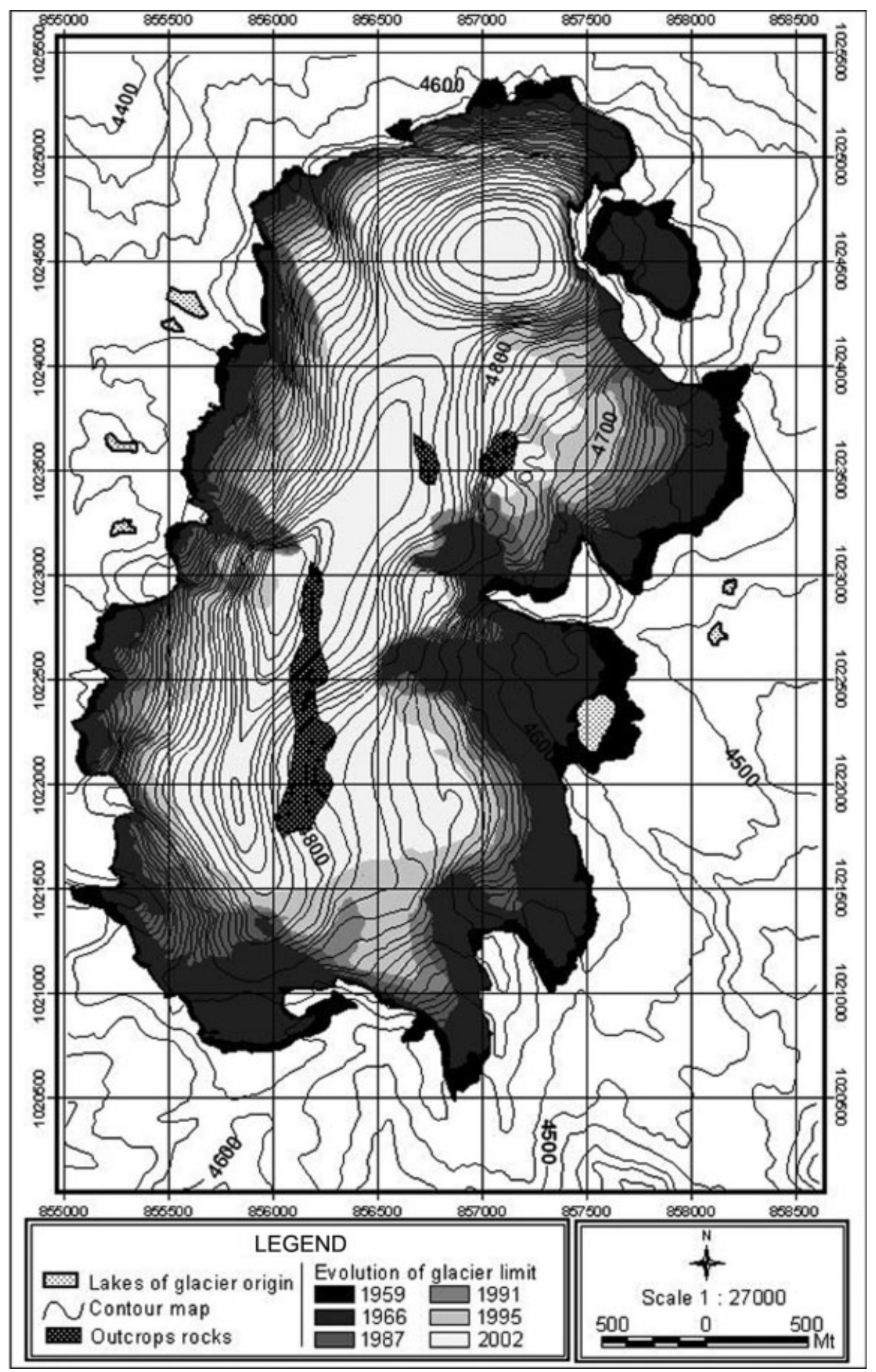

Fig. 2. Glacier extent on Nevado de Santa Isabel in the years 1959, 1966, 1987, 1991, 1995 and 2002.

indicate the influence of local topography and microclimate on the behaviour of the glaciers. Based on the data currently available, the factors controlling mass-balance and glacier length/area change in Colombia cannot yet be quantitatively assessed.

The most significant glacier retreat, with up to $50 \%$ area loss in the last 20 years, was observed in Sierra Nevada de Santa Marta and on Nevado de Santa Isabel. Sierra Nevada de Santa Marta, the location of the highest peak in Colombia (5775 ma.s.l.), is special due to its geographic location $<50 \mathrm{~km}$ from the Caribbean coast. The climatic regime thus differs from that of the other glacierized regions. The particularly rapid glacier retreat at Santa Marta and Santa Isabel may be related to the small size of glaciers in these areas. It is known that scale and edge effects become effective for glacier retreat when the glacier reaches a critical size. This is true for mid-latitude glaciers in general (Paul and others, 2004) and for tropical glaciers in particular (Francou and others, 2003). Heating due to solar radiation of rocks surrounding the glacier can imply local advection of warm air and thus can increase sensible-heat fluxes. It is suggested that the critical glacier size for the small ice cap on Nevado de Santa Isabel was reached in the 1990s. The extraordinary loss of almost $40 \%$ of its area in only 6 years 

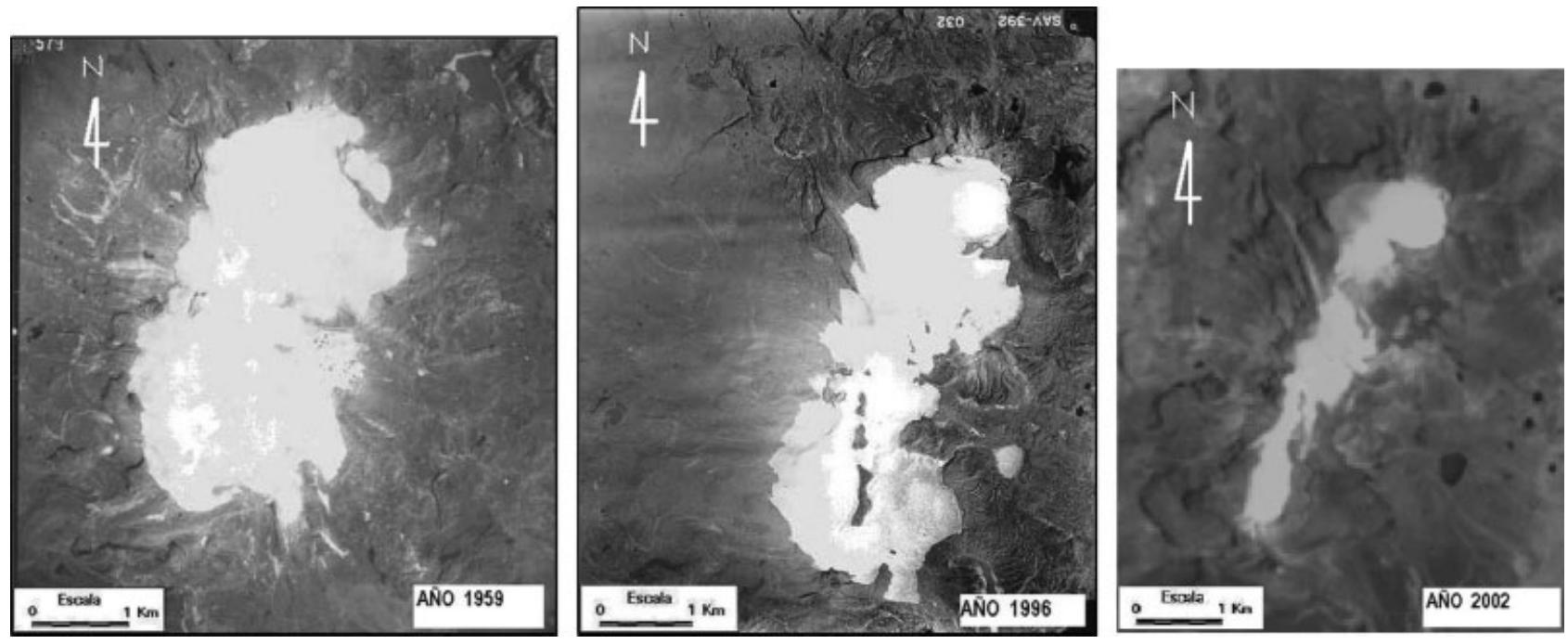

Fig. 3. Glacier extent on Nevado de Santa Isabel as seen from aerial photography in 1959 and 1996 and a Landsat Thematic Mapper satellite image in 2002.

from 1996 to 2002 supports this hypothesis and makes a further rapid shrinkage likely.

The larger and compact ice caps on the active volcanoes Nevados del Ruiz and del Huila have experienced slightly (Ruiz) and significantly (Huila) smaller glacier retreat in the last 20 years. Scale and edge effects probably do not yet play a dominant role there. Pulgarín and others (1996) analyzed the glacier changes, including ice volume changes, on Nevado del Huila and found an accelerated loss of area and volume in the first half of the 1990s. Similarly, Linder (1991) reported an increased loss of glacier area and volume on Nevado del Ruiz, starting in the mid-1970s.

As mentioned above, there are not yet sufficient data available to analyze the causes of rapid glacier shrinkage in Colombia. There are, however, two high-mountain meteorological stations which have been recording since the mid1980s and since the mid-1970s, respectively. Data from the El Cocuy meteorological station document a rise in mean annual air temperature by roughly $1{ }^{\circ} \mathrm{C}$ during the 25 years prior to 2000 (Fig. 7). A temperature rise implies a

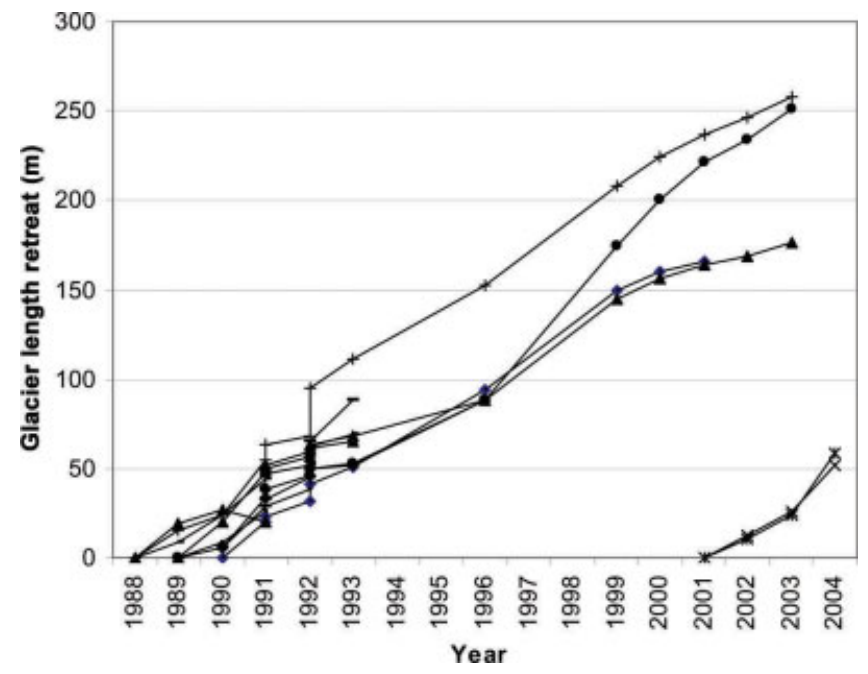

Fig. 4. Cumulative retreat of different glacier tongues of Nevado de Santa Isabel. corresponding rise in the equilibrium-line altitude (ELA) which often provokes an immediate reaction of the glacier tongues in tropical conditions (Kaser and Georges, 1997). It is thus apparent that air-temperature rise has had a major influence on glacier retreat during the last two decades, at least within the Sierra Nevada del Cocuy region, but it is unlikely to be the only factor. Kaser and Georges (1997) found that only about one-third of the glacier retreat in the outer tropics of the Peruvian Cordillera Blanca could be attributed to a temperature rise. For a glacier tongue on Nevado de Santa Isabel, air temperature from the meteorological station Las Brisas (12 km away) is compared to glacier retreat in the 1989-94 period in Figure 8. The comparison indicates that a temperature rise may lead to remarkably direct reactions at the glacier tongue, especially in the years 1990-92. The small size of the glaciers on Nevado de Santa Isabel implies a short response time, but the relation of the measured temperature rise and glacier retreat should be investigated in more detail.

Precipitation has a major direct and indirect influence on the mass balance of tropical glaciers. In addition to thermal homogeneity, the inner tropics are characterized by relatively constant seasonal humidity conditions, even though

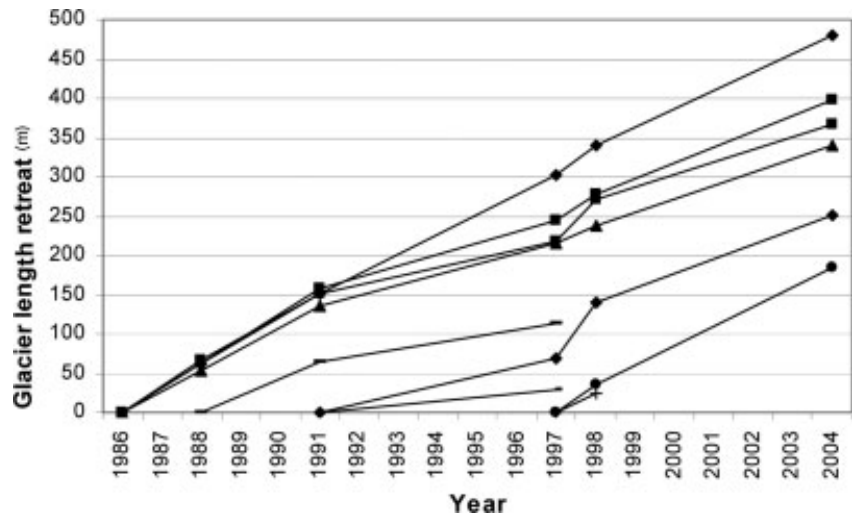

Fig. 5. Cumulative retreat of different glacier tongues in Sierra Nevada del Cocuy. 


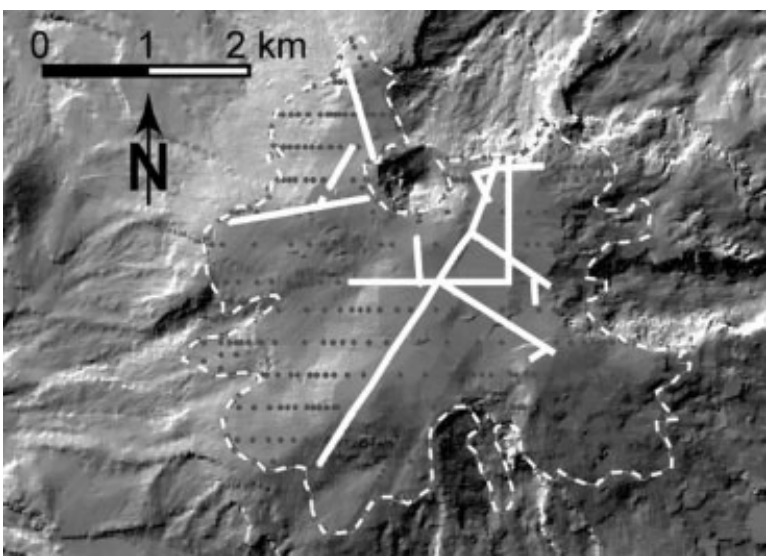

Fig. 6. Shaded relief plot of the glacier surface of Nevado del Ruiz based on a geodetic survey and photogrammetric generation of a digital terrain model. Bold white lines indicate profiles of GPR measurements. Grey dots represent point locations used for interpolation of the bed topography. Glacier extent is indicated by a dashed line.

the intra-annual variability can be quite high. The seasonality is caused by the oscillation of the Intertropical Convergence Zone which brings peak precipitation seasons from March to May and from September to November in Colombia. Figure 9 shows the precipitation record of the El Cocuy station during the El Niño years 1997-98, with decreased precipitation. Indirect effects of precipitation variability on glacier mass balance act through feedback mechanisms on albedo. Wagnon and others (2001) claim that the albedo feedback is actually far more effective in explaining the variability of annual mass balance than the annual variability of accumulation. The effect of precipitation and related albedo changes on the glacier length variation in the El Cocuy region can clearly be observed for the 1997-98 period in Figure 5.

On the other hand, humid conditions with an excess of precipitation such as produced by the La Niña phenomenon in 1999 have slowed down the glacier retreat. Figure 10 documents the precipitation record during this period at the Laguna Otún meteorological station $5 \mathrm{~km}$ from Nevado de Santa Isabel. Lower temperatures, increased snow accumulation on the glacier, and reduced direct radiation during the 1999 La Niña further contributed to a lower than normal glacier retreat of $7-8 \mathrm{~m}$ in this year.

Euscátegui (2002, 2003) analyzed the relationship of climatic parameters to glacier length changes on Nevado de

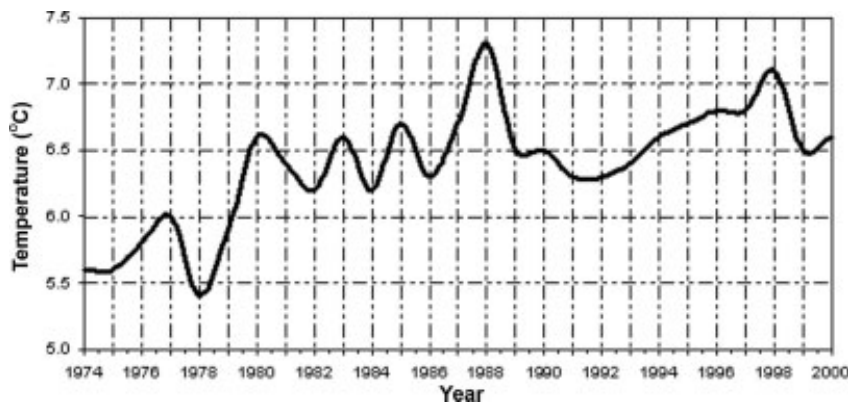

Fig. 7. Mean annual temperature (1974-2000) recorded at the El Cocuy meteorological station $\left(6^{\circ} 26^{\prime} \mathrm{N}, 72^{\circ} 23^{\prime} \mathrm{W} ; 3716 \mathrm{~m}\right.$ a.s.I. $)$.

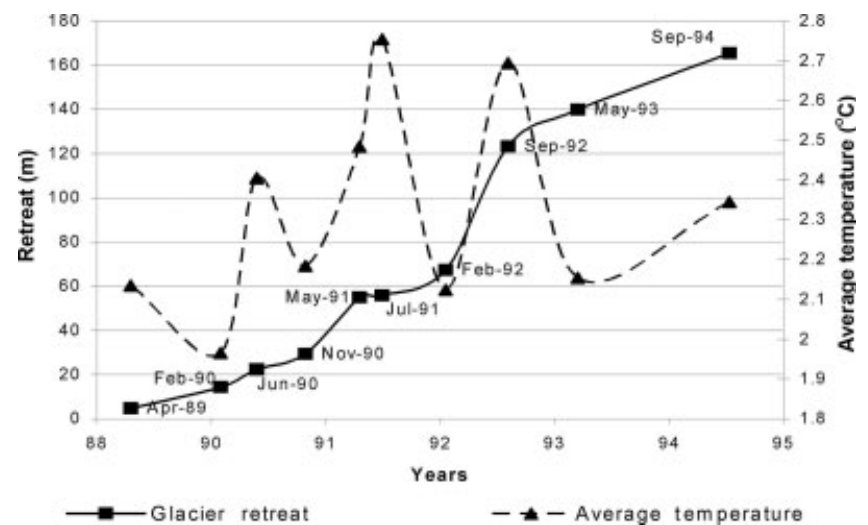

Fig. 8. Mean monthly temperature recorded at the Las Brisas meteorological station $\left(4^{\circ} 56^{\prime} \mathrm{N}, 75^{\circ} 21^{\prime} \mathrm{W} ; 4150 \mathrm{~m}\right.$ a.s.l.) and retreat of a glacier terminus at Nevado de Santa Isabel.

Santa Isabel. According to the regression model applied, maximum temperature, relative humidity and solar radiation are the parameters which show the highest correlation with glacier retreat. These findings are consistent with recent studies from tropical glaciers. Kaser (1999), for instance, showed that changes in air humidity are a dominant factor for glacier retreat in the tropics. Similarly, in the Andes, glacier retreat was accompanied by an increase in nearsurface temperature and a decrease in specific and relative humidity (Vuille and others, 2003).

Although the accelerated retreat of glaciers in the last 20 years, such as observed in Colombia, is a global phenomenon, this climate-related development has a specific dimension in the tropics. The usually small size of glaciers in the tropics, in particular in the inner tropics, makes them respond to climate signals at very short timescales (Francou and others, 2003). Due to the small elevation range of these glaciers, a rise in the ELA of $\sim 100 \mathrm{~m}$ may expose the entire glacier to predominantly ablation conditions. Glacier decay or even disappearance is a consequence observed in several tropical regions (e.g. Bolivia (Ramírez and others, 2001); the African Rwenzori and Mount Kenya massifs (Hastenrath and Kruss, 1992; Kaser and Osmaston, 2002)). Apart from the development in Colombia, the most remarkable glacier retreat in innertropical regions has occurred in Irian Jaya, where in only 18 years (1972-90) a 57\% retreat of the glacierized area was measured (Kaser and Osmaston, 2002). In the Rwenzori mountains, a 56\% loss of glacier area between 1955 and 1990 was reported (Kaser and Osmaston, 2002), while glacier shrinkage on Mount Kenya amounted to $17 \%$ during the 6 year period 1987-93 (Hastenrath, 1995).

Table 2. Glacier surface area, ice thickness and estimated volume on Nevado del Ruiz according to GPR measurements

Max. elevation

Glacierized area (1999)

Max. ice thickness

Average ice thickness

Total ice volume

Ice density (derived from uppermost $3 \mathrm{~m}$ drilled)

Total ice volume (water equivalent)
$5320 \mathrm{~m}$ a.s.l.

$11.58 \mathrm{~km}^{2}$

$190 \mathrm{~m}$

$47 \mathrm{~m}$

$0.57 \mathrm{~km}^{3}$

$680 \mathrm{~kg} \mathrm{~m}^{-3}$

$0.38 \mathrm{~km}^{3}$ w.e 


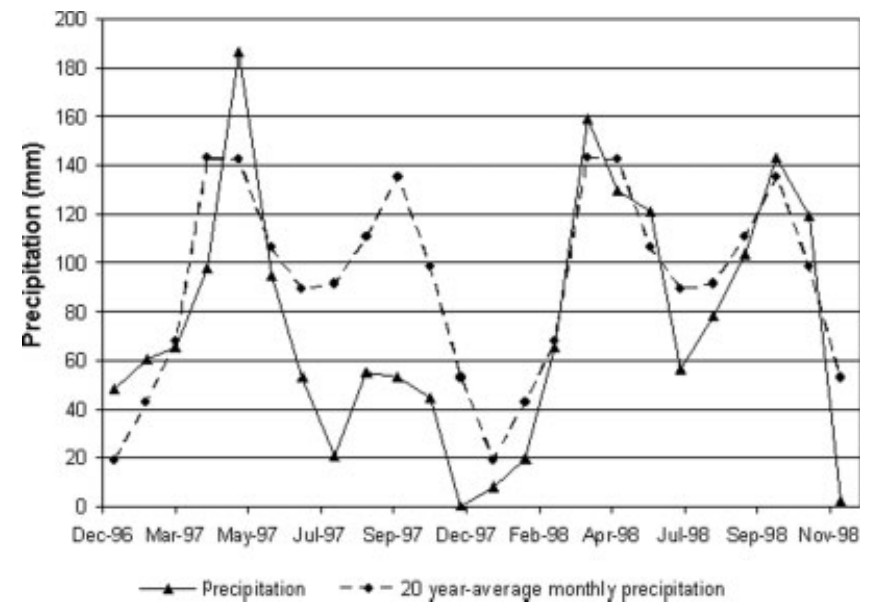

Fig. 9. Precipitation at the El Cocuy meteorological station during the 1997-98 El Niño phenomenon, as opposed to the 20 year average monthly precipitation. Note the strong precipitation deficit between June 1997 and February 1998.

Glacier disappearance in the tropics is, in fact, already part of current developments. The disappearance of several Colombian glaciers in the recent past has already been mentioned. Similar processes were recently observed in Mexico where glacier disappearance was accelerated by continuous volcanic activity (Huggel and Delgado, 2000; Julio Miranda and others, in press), a phenomenon especially relevant to Colombia where several glaciers are located on active volcanoes.

\section{CONCLUSIONS AND PERSPECTIVES}

This paper presents new data on the dramatic retreat of glaciers in Colombia. These are among the few glaciers still existing in the inner tropics and are significant indicators of regional and global climate change. Nevertheless, little has been known so far of the behaviour and change of glaciers in Colombia. The present contribution documents the most important glacier fluctuations in Colombia and thus adds to the few existing studies on tropical, particularly innertropical, glaciers, which draw a similarly dramatic picture of glacier shrinkage and continuing glacier disappearance.

Recently initiated mass-balance measurements on Nevado de Santa Isabel will contribute to better exploration of the specific climate-glacier interaction in Colombia. After a geodetic survey of the ice surface, ablation and accumulation stakes are being installed in a glacier sub-catchment along a west-east transect. Logistics and irregular ablation and accumulation cycles are among the main challenges of mass-balance measurements on high-elevation glaciers in the inner tropics. Nevertheless, it is considered of high importance to strengthen glaciological studies in the tropics, in particular in the inner tropics, due to the strong climatic relevance of such glaciers and the continuing dramatic shrinkage and disappearance processes.

\section{ACKNOWLEDGEMENTS}

Part of the present study was conducted within the scientific exchange program supported by the Swiss State Secretariat for Economic Affairs. Support by E. Jordan and comments on the manuscript by M. Zemp are appreciated. Two anonymous reviewers made helpful comments and improved the paper.

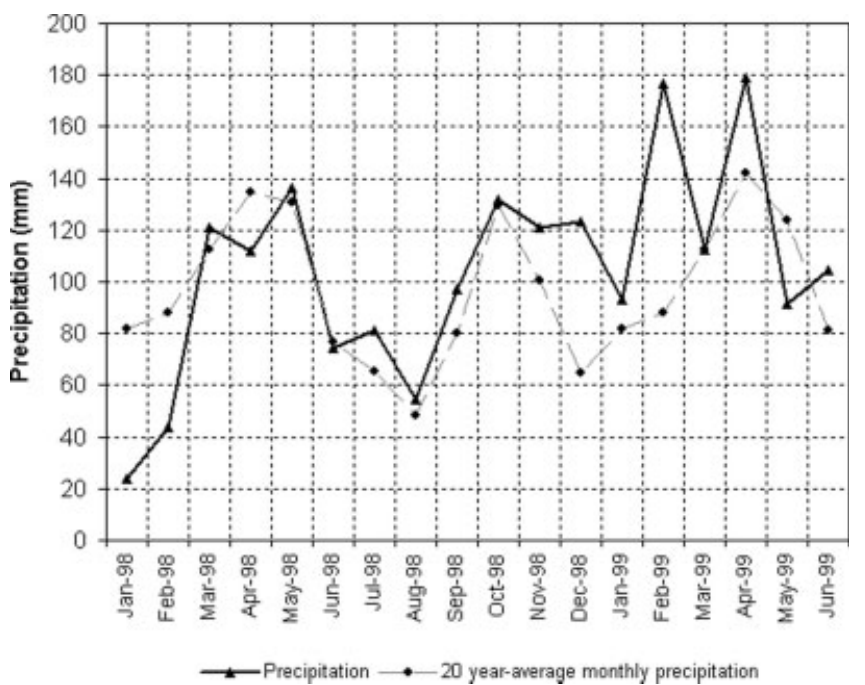

Fig. 10. Precipitation at the Laguna Otún meteorological station $\left(4^{\circ} 46^{\prime} \mathrm{N}, 75^{\circ} 24^{\prime} \mathrm{W} ; 3960 \mathrm{~m}\right.$ a.s.I.) between January 1998 and June 1999 , as opposed to the 20 year average monthly precipitation. The excess of precipitation can be observed for the period November 1998-April 1999.

\section{REFERENCES}

Braitmeier, M. 2003. Die Energiebilanz an der Oberfläche des Nevado Santa Isabel, Kolumbien. (PhD thesis, HeinrichHeine-Universität Düsseldorf.)

Euscátegui, C. 2002. Incidencia de las variaciones del brillo solar en la dinámica glaciar del volcán Nevado Santa Isabel (Cordillera Central, Colombia). Meteorol. Colomb., 6, $1-11$.

Euscátegui, C. 2003. Estado de los glaciares en Colombia y análisis de la dinámica glaciar en el Parque Los Nevados, asociada al Cambio Climático Global. (MSc thesis, Universidad Nacional de Colombia.)

Favier, V., P. Wagnon, J.P. Chazarin, L. Maisincho and A. Coudrain. 2004. One-year measurements of surface heat budget on the ablation zone of Antizana Glacier 15, Ecuadorian Andes. J. Geophys. Res., 109(D18), D18105. (10.1029/2003JD004359.)

Flórez, A. 1992. Los nevados de Colombia, glaciales y glaciaciones. Anál. Geogr., 22, 15-55.

Francou, B., M. Vuille, P. Wagnon, J. Mendoza and J.E. Sicart. 2003. Tropical climate change recorded by a glacier in the central Andes during the last decades of the twentieth century: Chacaltaya, Bolivia, $16^{\circ} \mathrm{S}$. J. Geophys. Res., 108(D5), 4154. (10.1029/2002JD002959.)

Hastenrath, S. 1989. Ice flow and mass changes of Lewis Glacier, Mount Kenya, East Africa: observations 1974-86, modelling, and predictions to the year 2000 A.D. J. Glaciol., 35(121), $325-332$.

Hastenrath, S. 1995. Glacier recession on Mount Kenya in the context of the global tropics. Bull. Inst. Fr. Étud. Andin., 24(3), 633-638.

Hastenrath, S. and P.D. Kruss. 1992. The dramatic retreat of Mount Kenya's glaciers between 1963 and 1987: greenhouse forcing. Ann. Glaciol., 16, 127-133.

Hope, G.S., J.A. Peterson, U. Radok and I. Allison. 1976. The equatorial glaciers of New Guinea: results of the 1971-1973 Australian Universities' Expeditions to Irian Jaya: survey, glaciology, meteorology, biology and palaeoenvironments. Rotterdam, A.A. Balkema.

Houghton, J.T. and 7 others. 2001. Climate change 2001: the scientific basis. Contribution of Working Group I to the Third Assessment Report of the Intergovernmental Panel on Climate Change. Cambridge, etc., Cambridge University Press. 
Huggel, C. and H. Delgado. 2000. Glacier monitoring at Popocatépetl volcano, México: glacier shrinkage and possible causes. In Hegg, C. and D. Vonder Mühll, eds. Beiträge zur Geomorphologie - Proceedings der Fachtagung der Schweizerischen Geomorphologischen Gesellschaft. Birmensdorf, Eidgenössische Forschungsanstalt WSL, 97-106.

Huggel, C., J.L. Ceballos, J. Ramírez, B. Pulgarín and J.C. Thouret. In press. Review and reassessment of hazards owing to volcanoglacier interactions in Colombia. Ann. Glaciol., 45.

Julio Miranda, P., H. Delgado Granados, C. Huggel and A. Kääb. In press. Impact of the eruptive activity on glacier evolution at Popocatépetl volcano (México) during 1994-2001. J. Volcan. Geotherm. Res.

Kaser, G. 1999. A review of the modern fluctuations of tropical glaciers. Global Planet. Change, 22(1-4), 93-103.

Kaser, G. and C. Georges. 1997. Changes of the equilibrium-line altitude in the tropical Cordillera Blanca, Peru, 1930-50, and their spatial variations. Ann. Glaciol., 24, 344-349.

Kaser, G. and C. Georges. 1999. On the mass balance of low latitude glaciers with particular consideration of the Peruvian Cordillera Blanca. Geogr. Ann., 81A(4), 643-651.

Kaser, G. and H. Osmaston. 2002. Tropical glaciers. Cambridge, etc., Cambridge University Press.

Linder, W. 1991. Klimatisch und eruptionsbedingte Eismassenverluste am Nevado del Ruiz, Kolumbien, während der letzten 50 Jahre. Eine Untersuchung auf der Basis digitaler Höhenmodelle. (PhD thesis, Universität Hannover.)
Paul, F., A. Kääb, M. Maisch, T. Kellenberger and W. Haeberli. 2004. Rapid disintegration of Alpine glaciers observed with satellite data. Geophys. Res. Lett., 31(21), L21402. (10.1029/ 2004GL020816.)

Pulgarín, B., E. Jordan and W. Linder. 1996. Nevado del Huila (Colombia): Cambio glaciar entre 1961 y 1995. In Proceedings VII Congreso Colombiano de Geologia, Tome I. Ingeominas. Santafé de Bogotá, 440-451.

Ramírez, E. and L.F. Guarnizo. 1994. Valores de ablación de un relicto de glaciar en el volcán Nevado del Ruiz utilizando metodos topográficos. Bol. Vias, 80, 85-112.

Ramírez, E. and 8 others. 2001. Small glaciers disappearing in the tropical Andes: a case-study in Bolivia: Glaciar Chacaltaya (16 ${ }^{\circ}$ S). J. Glaciol., 47(157), 187-194.

Schubert, C. 1972. Geomorphology and glacier retreat in the Pico Bolivar area, Sierra Nevada de Mérida, Venezuela. Z. Gletscherkd. Glazialgeol., 8(1-2), 189-202.

Thouret, J.C. 1990. Effects of the November 131985 eruption on the snowpack and ice cap of Nevado del Ruiz volcano, Colombia. J. Volcan. Geotherm. Res., 41(1-4), 177-201.

Vuille, M., R.S. Bradley, M. Werner and F. Keimig. 2003. 20th Century climate change in the tropical Andes: observations and model results. Climatic Change, 59(1-2), 75-99.

Wagnon, P., P. Ribstein, B. Francou and J.E. Sicart. 2001. Anomalous heat and mass budget of Glaciar Zongo, Bolivia, during the 1997/98 El Niño year. J. Glaciol., 47(156), 21-28. 